\title{
Quality of the reef fish Upeneus tragula (Mullidae) at settlement: is size a good indicator of condition?
}

\author{
Mark I. McCormick, Brett W. Molony \\ Department of Marine Biology, James Cook University, Townsville, Queensland 4811, Australia
}

\begin{abstract}
The quality at settlement of the goatfish Upeneus tragula (family Mullidae) was examined from 10 samples collected over 2 summers (1990/1991, 1991/1992), at 1 location near Lizard Island on the northern Great Barrier Reef, Australia. Nine commonly used measures of fish condition were employed: standard length (SL), body depth at the pectoral fin, total lipid content, carbohydrate content, protein content, water content, growth rate, burst swimming speed and Fulton's condition factor $\left(K=\right.$ weight $/ \mathrm{SL}^{3}$ ). High and significant levels of variability were found in all measures of condition over the 10 samples. There was no relationship between the age of the fish at settlement and total carbohydrate and lipid content or burst speed of fish. Correlations of measures of condition with fish length were very poor. Specifically, burst speed and stored energy levels (lipids, carbohydrates) had particularly low correlations with fish length $(r<0.2)$. An experiment determined that burst speed of a fish at settlement was not related to its feeding history within the larval stage. Feeding history only accounted for $6 \%$ of the total variation in burst speeds. Most of the variability in measures of condition were due to differences among individuals. The poor correlations between all measures of fish quality (with exception of morphological measures) suggest no single measure gives an adequate description of a fish's survival potential. Furthermore, this study cautions against the direct transfer of size-based theories of success (i.e. 'bigger is better') to the variability within a specific developmental stage.
\end{abstract}

\section{INTRODUCTION}

Recent reviews of larval fish ecology stress the importance of events that occur during the early larval stage in influencing the quality or health of the larvae, and ultimately which individuals survive to recruit into the juvenile population (e.g. Miller et al. 1988, Pepin 1989, 1991, Srivastava \& Brown 1991). These reviews stress the multiplicative benefits of being larger than average throughout the larval period, where an advantage in size flows on to advantages in sensory and somatic development, capture of food and escape from predation (Bailey \& Batty 1984, Eaton \& DiDomenico 1986, Miller et al. 1988, Bailey \& Houde 1989, Miller et al. 1992). Although many researchers have looked at condition of fish larvae, most have examined it over a wide size range, spanning a range of developmental states (e.g. Yin \& Blaxter 1987, Fuiman 1989, Margulies 1989). When such an array of developmental states, ranging from naive to com- petent, are incorporated into the same analysis, strong positive relationships with measures of success (e.g growth rate, mortality rates, biochemical condition) are to be expected (e.g. Margulies 1989). To date, researchers have been interested in the shape of the relationship between size and aspects of condition, and have ignored the associated variability.

It is of interest to know the levels of variability in traits that measure potential success or condition at a particular developmental stage, and whether the same hypotheses regarding survival capabilities hold at this smaller scale. Small differences in growth rate and quality during the larval stage, when the processes of differentiation and growth are fastest, can determine the strength of a recruitment event (Miller et al. 1988, Beyer 1989, Houde 1989). Furthermore, on an individual level, these differences in quality may be accentuated by post-recruitment processes and may influence which fish reach maturity. 
For reef fish, the transition from pelagic larva to demersal juvenile can represent an important numerical filter (Blaxter 1988), during which time larval condition may play a crucial role. Recent studies identify settlement as a period of major physiological (Pfeiler \& Luna 1984) and developmental remodelling (McCormick \& Shand in press). Some fish do not feed during this metamorphosis (e.g. Pfeiler 1986), which may take hours to months (Pfeiler \& Luna 1984, Markle et al. 1992); instead they have to survive on energy reserves stored during the pelagic stage. The present study examines the quality of newly settled reef fish from 10 samples collected over 2 summers from the same location on the northern Great Barrier Reef, Australia. In doing so it highlights the potential importance of the high levels of variability in condition found during this transition.

Many methods have been used to measure aspects of the physiological and structural quality in fishes (Bolger \& Connolly 1989). These can be categorised into direct (e.g. morphological measures) and derived methods (e.g. residuals from regressions of logged length and lipid levels; Suthers et al. 1992). The present study compares 9 direct methods of assessing the quality of a reef fish at settlement. Two morphological measures are compared with more intensive biochemical determinations of body composition, growth rates, Fulton's condition factor $[K=$ weight / (standard length) ${ }^{3}$ ] and burst speed. Here, burst speed is used as a measure of the fish's ability to survive, being important to both the success of capturing food items (Laurence 1972) and the ability to escape predators (Webb 1981). Since the feeding history within the pelagic stages has been shown to affect the growth characteristics of a reef fish at settlement (McCormick \& Molony 1992), it is of interest to know whether feeding history also influences the fish's burst speed when it first encounters the reef population.

Specifically, we used the newly settled stage of the goatfish Upeneus tragula (family Mullidae) to approach the following questions. How much variability is there in the quality of a newly settled reef fish measured in various ways? Can any of this variability be explained by the age of the fish at settlement? Does food availability during the pelagic stages influence a fish's probability of survival at settlement? How do standard methods of measuring condition (e.g. Fulton's $K)$ compare to more detailed methods? Is there a good, easily measured predictor of quality of $U$. tragula at settlement? Finally, to what extent can the size-related theories of which factors determine survival in the plankton (i.e. 'bigger-is-better'; Litvak \& Leggett 1992) be transferred to the period of settlement to the reef? In answering these questions we emphasize that fish of a particular species may not start their reef-associated life with an equal probability of survival.

\section{MATERIALS AND METHODS}

Sampling. Ten samples of pelagic-stage mullids were collected $5 \mathrm{~km}$ north of Eagle Island $\left(14^{\circ} 42^{\prime} \mathrm{S}\right.$, $\left.145^{\circ} 23^{\prime} \mathrm{E}\right)$ on the northern Great Barrier Reef over 2 summers (December 1990 to January 1991, November 1991 to December $1992_{i}$ for dates see Fig. 1). Floating plastic rafts $(1 \times 1 \mathrm{~m})$ were used to aggregate the mullids, which were then caught with a $14 \times 2 \mathrm{~m}$ plankton-mesh purse seine $(0.5 \mathrm{~mm}$ mesh). All Upeneus tragula were carefully transferred into lidded 30 to 701 black buckets containing aerated seawater. Fish were then rapidly transported to the Lizard Island Research Station, where the buckets were connected to a flow-through seawater system. Those fish that settled the night after capture were processed. It was assumed that these individuals were competent to settle when caught and would have settled that night.

Variability in the quality of newly settled fish. All newly settled fish were killed by cold shock. Standard length (SL), body depth at the pectoral fin (BDP) and wet weight were obtained fresh. Fish were preserved in liquid nitrogen for biochemical examination. Total lipid, carbohydrate, protein and water content $\left(\mathrm{mg} \mathrm{g}^{-1}\right.$ wet wt) was determined for 10 fish randomly selected from each sample. Biochemical determinations were duplicated for each fish. Methods are detailed by McCormick \& Molony (1992).

Measurement of burst speed. Burst speeds were measured for 165 newly settled Upeneus tragula from 8 samples collected during November-December 1991 (see Fig. 1 for dates) and also measured for all fish from the feeding experiment (detailed below). Burst speeds were measured in a long narrow tank $(5 \times 20 \times 75 \mathrm{~cm})$ which restricted the fish's movement largely to 2 dimensions. The back and sides of the tank were blackened and scale bars were placed on the back of the tank. Water temperature during the burst speed trials was the same as the holding tanks and lagoonal waters at ca $28^{\circ} \mathrm{C}$. Newly settled fish were placed into the burst speed tank, left for 3 to $5 \mathrm{~min}$ to acclimatise then stimulated. This involved tapping the fish with a perspex probe at the base of the tail. After approximately $10 \mathrm{~s}$, the fish was left to recover for 3 to $5 \mathrm{~min}$ and then stimulated again. This was continued until exhaustion or until a number of good bursts had been recorded. Burst motion was obvious and 3 fish that failed to give a burst speed under these conditions were excluded from the analysis. A video camera (Panasonic NVN7A, 25 frames $\mathrm{s}^{-1}$ ) was used to record the fishes' movements. The progression of the head was traced and the distance moved between consecutive frames of the video tape was determined (Panasonic video recorder AG7330 linked with Jandel 
video analysis software), allowing the maximum burst speed to be calculated. Biochemical composition was determined for a random sample of 10 fish from each of the 8 samples for which burst speeds were recorded. Studies of the effects of forced exercise on fish body composition have shown that the changes that occur in the biochemistry of fish within 5 to $10 \mathrm{~min}$ of intermittent exercise will be minor, involving the change of glycogen to glucose in the liver (e.g. Love 1980, Gamperl et al. 1988, Schwalme \& Mackay 1991). These changes will not influence the body constituents when measured as total carbohydrate, lipid and protein.

Comparison of measures of condition. Nine methods of quantifying fish condition were compared: standard length (SL), body depth at the pectoral fin, total lipid content, carbohydrate content, protein content, water content, growth rate, burst speed and Fulton's condition factor $\left[K=\right.$ weight $\left.(\mathrm{kg}) / \mathrm{SL}(\mathrm{m})^{3}\right]$. All 9 indices were measured for each fish $(n=100$, except for burst speed where $n=80$ ). The indices were chosen due to their extensive use in the literature. Average growth rate over the larval phase was determined by dividing the length at settlement (minus an estimated hatching length of $2 \mathrm{~mm}$ ) by the age at settlement. Age was determined by counting microstructural increments on transverse sections of the sagittal otoliths. These have been validated as daily (McCormick 1993). Trends in the 9 measures of condition were compared graphically over the 10 samples of newly settled Upeneus tragula, and the correlations among measures were examined.

Effect of feeding history on burst speed at settlement. To examine the influence of feeding history on the burst speed of the fish at settlement, pelagic-stage Upeneus tragula were fed 5 different food quantities until settlement. The experiment was conducted between 16 November and 19 December 1991. Pelagic U. tragula were caught as detailed above and those of a similar length (20 to $23 \mathrm{~mm} \mathrm{SL}$ ) were randomly placed into ten $60 \mathrm{l}$ aquaria (25 fish tank $\mathrm{k}^{-1}$ ), representing 2 tanks in each of the 5 feeding treatments. Fish were fed 36 to 48 h old Artemia sp. nauplii (Artemia 90 brand). Food was added to each of the tanks 4 times a day, in concentrations that were calculated to result in the following densities after introduction: (a) Fed ad libitum (1600 nauplii 1-1); (b) 4/5 Fed (1280 nauplii $\mathrm{l}^{-1}$ ); (c) 3/5 Fed (960 nauplii $\mathrm{l}^{-1}$ ); (d) 2/5 Fed (640 nauplii $1^{-1}$ ); (e) 1/5 Fed (320 nauplii $1^{-1}$ ).

Fish that metamorphosed and settled avernight in the treatment tanks were removed prior to feeding the following morning. Fish were in the tanks for between 6 and $34 \mathrm{~d}$ (mean $15.6 \mathrm{~d}$ ) prior to metamorphosis. Burst speeds were obtained for each settled fish, and their morphology and weights recorded as above.

\section{RESULTS}

\section{Variability in quality of newly settled fish}

The levels of total lipids, carbohydrates and proteins were found to vary significantly among the 10 samples of newly settled Upeneus tragula (Table 1). Levels of mean lipid and protein concentrations showed close correspondence (Fig. 1), with those samples registering high lipid levels also having high protein levels. Mean lipid levels per sample ranged from 21 to $46 \mathrm{mg} \mathrm{g}^{-1}$ wet wt. Carbohydrates showed no relationship to protein or lipid levels. Although the 2 samples from December 1990 and January 1991 were highest in lipids and proteins, they exhibited both the highest and lowest levels of carbohydrate (Fig. 1).

Age at settlement was found to account for a minor and nonsignificant amount of the variability in body constituents and burst speed (Fig. 2). The variation explained by age was less than $0.2 \%$ for all the biochemical constituents (carbohydrate: $\mathrm{r}^{2}=0.002, \mathrm{p}>0.6$; lipid: $r^{2}=0.0004, p>0.8 ;$ protein: $r^{2}=0.0007, p>0.8$;

Table 1. Upeneus tragula. One-way ANOVAs comparing the body composition and morphological attributes of newly settled fish from 10 samples taken over 2 summers ( $n=10$, except for burst speed where $n$ is variable). Percentages of the total variation explained by each factor are also given; formula from Winer (1971)

\begin{tabular}{|c|c|c|c|c|c|}
\hline Variable & $\begin{array}{l}\text { Source of } \\
\text { variation }\end{array}$ & df & Mean square & $\mathrm{p}$ & $\begin{array}{c}\text { Percent } \\
\text { variation }\end{array}$ \\
\hline $\begin{array}{l}\text { Lipid } \\
\left(\mathrm{mg} \mathrm{g}^{-1}\right)\end{array}$ & $\begin{array}{l}\text { Sample } \\
\text { Residual }\end{array}$ & $\begin{array}{r}9 \\
90\end{array}$ & $\begin{array}{l}622.32 \\
51.16\end{array}$ & 0.0001 & $\begin{array}{l}52.7 \\
47.3\end{array}$ \\
\hline $\begin{array}{l}\text { Protein } \\
\left(\mathrm{mg} \mathrm{g}^{-1}\right)\end{array}$ & $\begin{array}{l}\text { Sample } \\
\text { Residual }\end{array}$ & $\begin{array}{r}9 \\
90\end{array}$ & $\begin{array}{l}98.93 \\
31.35\end{array}$ & 0.0024 & $\begin{array}{l}17.7 \\
82.3\end{array}$ \\
\hline $\begin{array}{l}\text { Carbohydrate } \\
\left(\mathrm{mg} \mathrm{g}^{-1}\right)\end{array}$ & $\begin{array}{l}\text { Sample } \\
\text { Residual }\end{array}$ & $\begin{array}{r}9 \\
90\end{array}$ & $\begin{array}{l}0.111 \\
0.003\end{array}$ & 0.0001 & $\begin{array}{l}70.6 \\
29.4\end{array}$ \\
\hline $\begin{array}{l}\text { Water } \\
\left(\mathrm{mg} \mathrm{g}^{-1}\right)\end{array}$ & $\begin{array}{l}\text { Sample } \\
\text { Residual }\end{array}$ & $\begin{array}{r}9 \\
90\end{array}$ & $\begin{array}{l}0.0001 \\
0.0001\end{array}$ & 0.4572 & $\begin{array}{r}1.5 \\
98.5\end{array}$ \\
\hline $\begin{array}{l}\text { Standard length } \\
(\mathrm{mm})\end{array}$ & $\begin{array}{l}\text { Sample } \\
\text { Residual }\end{array}$ & $\begin{array}{r}9 \\
90\end{array}$ & $\begin{array}{l}6.87 \\
1.88\end{array}$ & 0.0006 & $\begin{array}{l}21.0 \\
79.0\end{array}$ \\
\hline $\begin{array}{l}\text { Growth rate } \\
\left(\mathrm{mm} \mathrm{d}^{-1}\right)\end{array}$ & $\begin{array}{l}\text { Sample } \\
\text { Residual }\end{array}$ & $\begin{array}{r}9 \\
90\end{array}$ & $\begin{array}{l}0.0204 \\
0.0036\end{array}$ & 0.0001 & $\begin{array}{l}32.0 \\
68.0\end{array}$ \\
\hline $\begin{array}{l}\text { Fulton's } K \\
\left(\mathrm{~g} \mathrm{~mm}^{-3}\right)\end{array}$ & $\begin{array}{l}\text { Sample } \\
\text { Residual }\end{array}$ & $\begin{array}{r}9 \\
90\end{array}$ & $\begin{array}{l}22.50 \\
1.056\end{array}$ & 0.0001 & $\begin{array}{l}67.0 \\
33.0\end{array}$ \\
\hline $\begin{array}{l}\text { Burst speed } \\
\left(\mathrm{cm} \mathrm{s}^{-1}\right)\end{array}$ & $\begin{array}{l}\text { Sample } \\
\text { Residual }\end{array}$ & $\begin{array}{r}7 \\
157\end{array}$ & $\begin{array}{l}402.09 \\
220.77\end{array}$ & 0.0867 & $\begin{array}{r}4.8 \\
95.2\end{array}$ \\
\hline${ }^{a}$ Log transformed & & & & & \\
\hline
\end{tabular}



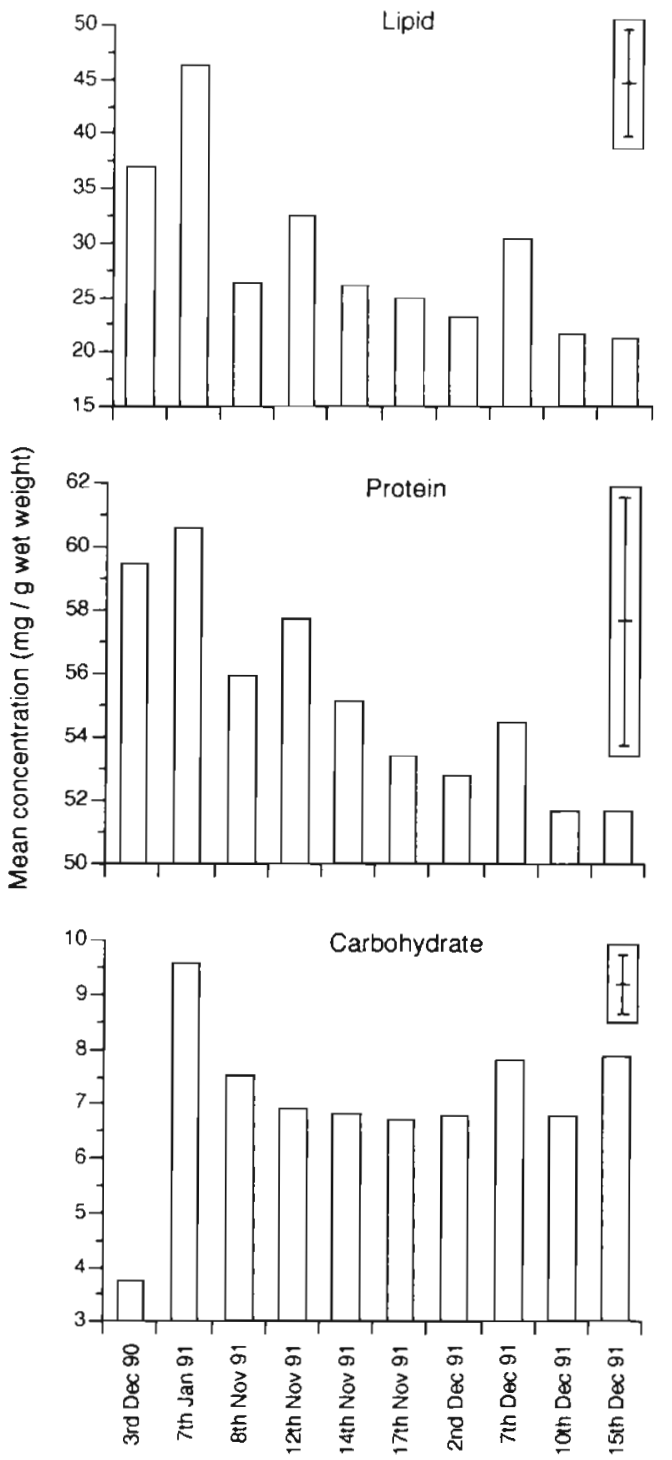

Fig. 1. Upeneus tragula. Content of total lipid, protein and carbohydrate in newly settled fish from 10 samples over 2 summers. Pooled $95 \%$ confidence limits are given $(n=10)$

water: $\left.r^{2}=0.001, p>0.7\right)$. Similarly low levels of variability in burst speed were explained by age (Fig. 2, $\left.\mathrm{r}^{2}=0.01, \quad \mathrm{p}>0.3\right)$. This suggests that for Upeneus tragula age does not confound the interpretation of the levels of variability in these measures of condition at settlement.

None of the biochemical constituents measured showed a strong relationship with standard length (Fig. 3), with partial correlation coefficients (adjusted for variable ages) ranging from 0.03 (protein) to 0.19 (carbohydrate) (Table 2). Total carbohydrates showed the highest variability, with a 5-fold difference between fish exhibiting the lowest and highest levels (2.4 to $13 \mathrm{mg} \mathrm{g}^{-1}$ wet $\left.w t\right)$. Lipids also ranged widely
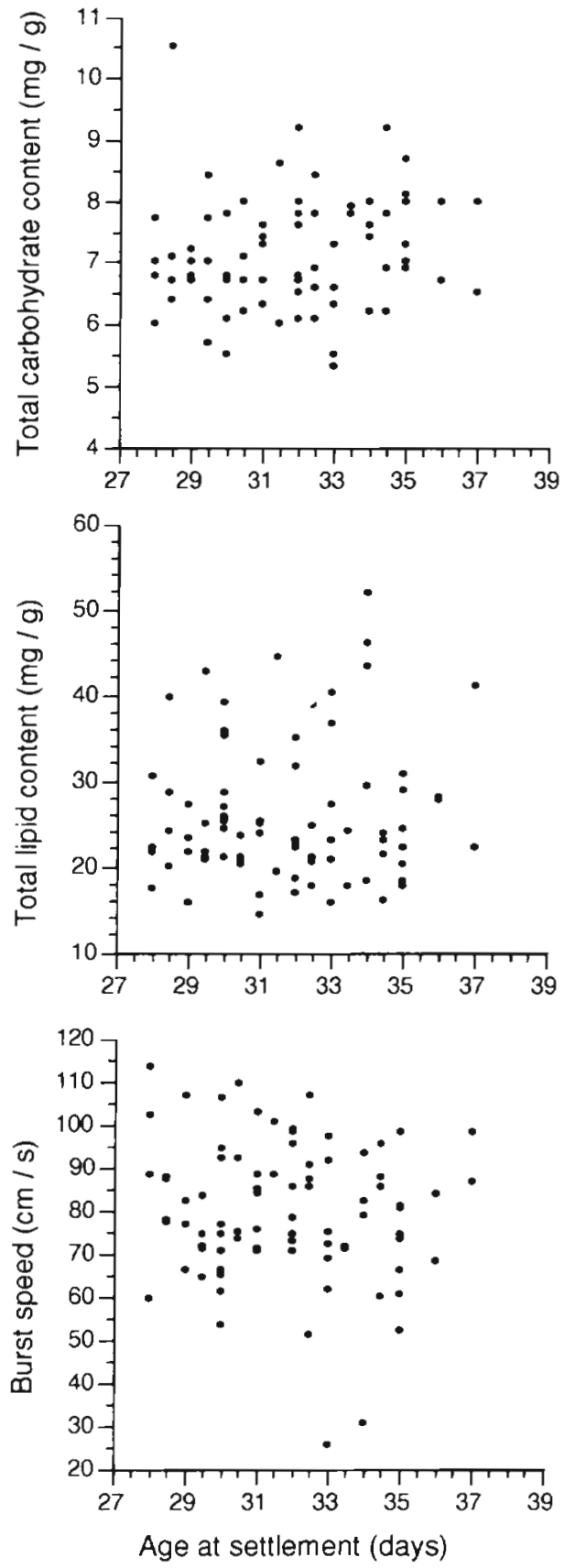

Fig. 2. Upeneus tragula. The influence of age of fish at settlement (d) on their total carbohydrate and lipid content $\left(\mathrm{mg} \mathrm{g}^{-1}\right.$ wet wt) and burst speed $\left(\mathrm{cm} \mathrm{s}^{-1}\right)$. All relationships are nonsignificant $(p>0.2)$

among fish (14 to $55 \mathrm{mg} \mathrm{g}^{-1}$ ). Over $50 \%$ of the total variation in lipids and carbohydrates was attributable to differences among samples 153 and $71 \%$ respectively, Table 1). On the other hand, most of the variation in water and protein content was due to differences among individual fish within the samples $(98.5$ and $82.3 \%$, Table 1 ). 


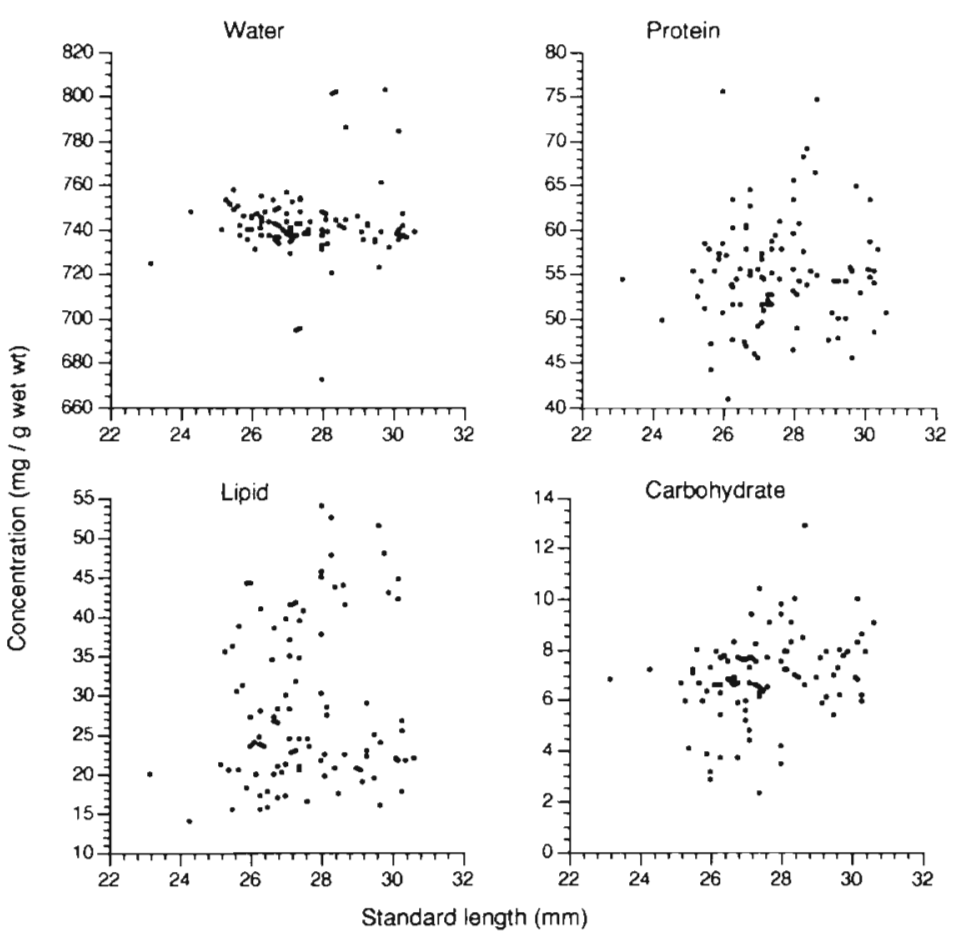

Fig. 3. Upeneus tragula. Relationship between standard length of newly settled fish and their biochemical composition. Relationships all nonsignificant except for carbohydrate $(r=0.199, p<0.05)$.

Burst speeds did not differ significantly among the 8 samples from November and December $1991(\mathrm{p}=0.09$, Table 1, Fig. 4). Ninety-five percent of the variation in burst speed was due to differences among individual fish within samples (Table 1). Burst speeds ranged from 25.5 to $123.4 \mathrm{~cm} \mathrm{~s}^{-1}$ (i.e. 8.4 to 42.5 body lengths (BL) $\mathrm{s}^{-1}$ ), with a mean of $81.8 \mathrm{~cm} \mathrm{~s}^{-1}$. Interestingly, burst speed showed no relationship with standard length, total carbohydrate or lipid l evels of the fish (Fig. 5, Table 2).

\section{Comparison of measures of condition}

Overall, there was little correspondence among the trends in the mean values of the 9 measures of condition over the 10 field samples (Fig. 6). However, there were exceptions. Fulton's $K$ exhibited a similar trend over the 10 field samples to that of fish growth rate. Body depth at the pectoral fin and total carbohydrate content also showed a strong similarity. Lastly, total lipid and protein content closely mapped one another. Trends in the burst speed among samples bore no relationship to trends in any of the other 8 measures of condition (Fig. 5).

On the level of individual fish, the correlations among measures were poor, with the exception of relationships between morphological measures (Table 2). Notably, growth rate over the whole larval period was significantly correlated with both standard length and body depth at the pectoral fin. Predictably, total lipid, carbohydrate and protein contents were negatively related to water content (Weatherley \& Gill 1987). Fulton's $K$ recorded some of the highest correlation coefficients with other measures of condition, and yielded the highest number of significant correlations (5). Burst speed fared the worst with only 1 significant correlation (Table 2). Stepwise multiple regressions of the 5 most easily measured indices of condition (i.e. SL, BDP, $K$, water content and growth rate) on burst speed, lipid, carbohydrate and protein content (on both nontransformed and logged data) were performed but the predictive ability was not increased over that of simple regressions.

Table 2. Upeneus tragula. Partial correlations, adjusted for age of fish, among 9 measures of quality of newly settled fish. Correlations with body depth at the pectoral fin (BDP) are adjusted for age and SL, except for the correlation between BDP and SL when only age is held constant. Correlations with growth rate are Pearson's correlations, as adjusting for age would be meaningless. Levels of significance are given $(" p<0.05 ; " p p<0.001)$. CHO: total carbohydrate; K: Fulton's condition factor ( $n=100$, except for burst when $\mathrm{n}=80$, since only 10 fish from each of the 8 Nov-Dec 1991 samples were analysed for biochemical composition)

\begin{tabular}{|c|c|c|c|c|c|c|c|c|c|}
\hline & SL & $\mathrm{BDP}$ & Lipid & $\mathrm{CHO}$ & Protein & Water & Growth & Burst & $K$ \\
\hline $\mathrm{SL}$ & 1.000 & $0.886^{\cdots}$ & 0.089 & 0.189 & 0.029 & -0.189 & $0.581 \cdots$ & 0.158 & $0.248^{\circ}$ \\
\hline $\mathrm{BDP}$ & & 1.000 & 0.165 & 0.128 & $-0.314^{*}$ & $0.199^{\circ}$ & $0.488^{\circ}$ & 0.183 & $0.613^{\circ}$ \\
\hline Lipid & & & 1.000 & $0.200^{\circ}$ & $0.358^{*}$ & $-0.388^{\cdots}$ & 0.014 & 0.082 & $-0.313^{\cdots}$ \\
\hline $\mathrm{CHO}$ & & & & 1.000 & 0.129 & $-0.419 \cdots$ & 0.060 & 0.116 & 0.155 \\
\hline Protein & & & & & 1.000 & $-0.365^{\circ}$ & -0.006 & 0.054 & $-0.461^{\cdots}$ \\
\hline Water & & & & & & 1.000 & -0.176 & -0.069 & 0.096 \\
\hline Growth & & & & & & & 1.000 & $0.208^{\circ}$ & 0.144 \\
\hline Burst & & & & & & & & 1.000 & $0.281^{\circ}$ \\
\hline K & & & & & & & & & 1.000 \\
\hline
\end{tabular}




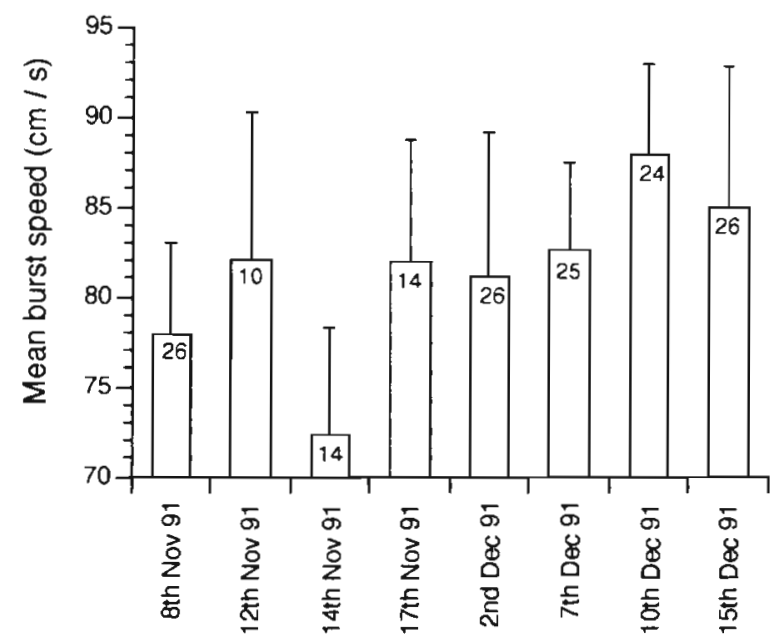

Fig. 4. Upeneus tragula. Mean burst speed of 8 samples of newly settled fish collected from 1 location on the northern Great Barrier Reef. Error bars are $95 \%$ confidence limits; $\mathrm{n}$ is variable and also given

\section{Effect of food quantity on burst speed at settlement}

The amount of food received during the late pelagic stage had little influence on the burst speed of Upeneus tragula at settlement under experimental conditions. Those fish in the $3 / 5$ Fed treatment had the highest mean burst speeds, while fishes that received the least food ( $1 / 5 \mathrm{Fed}$ ) had the lowest burst speeds (Fig. 7). In this experiment $88 \%$ of the variation in burst speed was due to differences among fish within the 10 tanks (Table 3 ). Burst speeds among the 5 feeding levels were not statistically significant (Table 3)

Time taken to settle was negatively related to food received, with those fish in the $1 / 5$ Fed treatment taking twice as long to settle as fish fed ad libitum $(24.8$ cf. 11.4 d). However, only $5 \%$ of the variation in burst speeds among treatments was explained by the time spent in the tanks prior to settlement $\left(r^{2}=0.05\right.$, $\mathrm{p}=0.008, \mathrm{n}=156$ ).

\section{DISCUSSION}

This study found high and significant variability in the condition of 10 samples of newly settled Upeneus tragula collected from 1 location on the northern Great Barrier Reef over 2 summers. Interestingly, the most ecologically meaningful measure of potential survival and success, burst swimming speed, was poorly correlated with standard methods of assessing condition. These conclusions have ramifications for the way we view reef fish replenishment. All reef fish may not start their reef-associated existence with equal probabilities
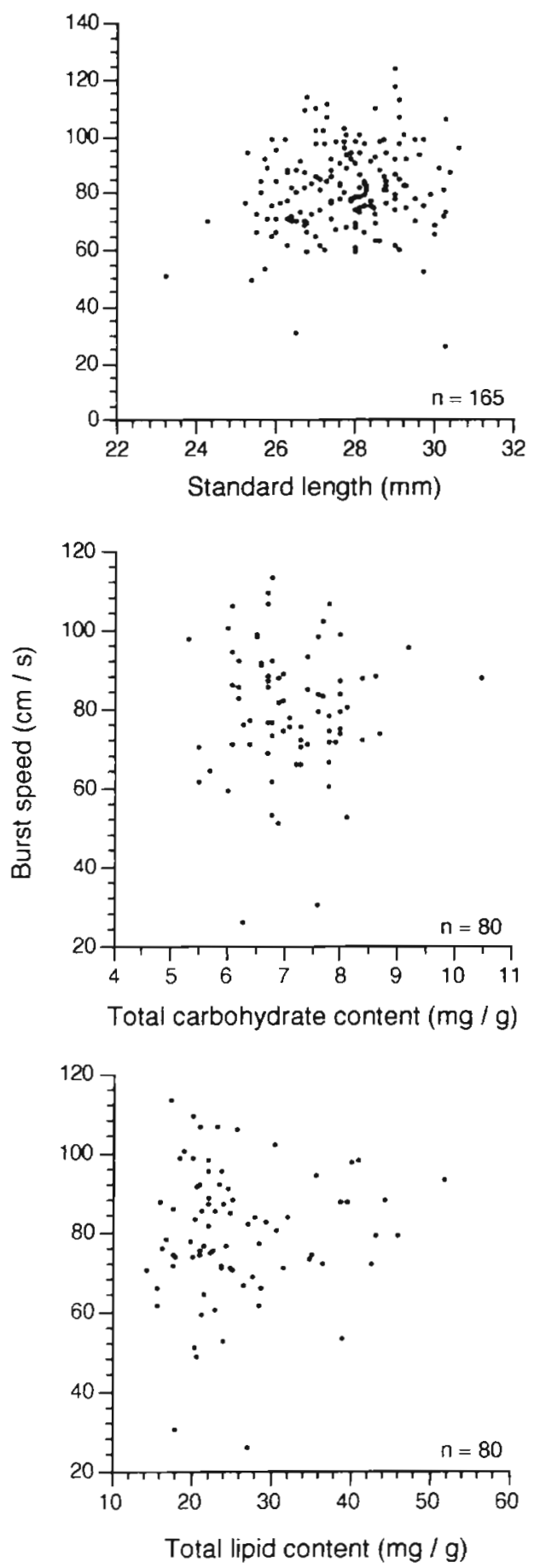

Fig. 5. Upeneus tragula. Relationship of burst speed with standard length, total carbohydrate and lupid concentrations of newly settled fish. Relationships are all nonsignificant $(p=0.22,0.37,0.52$ respectively $)$

of survival and success. Furthermore, the relative differences among fish at this developmental stage are not easily quantified. Size may not necessarily be a good proxy for condition. 

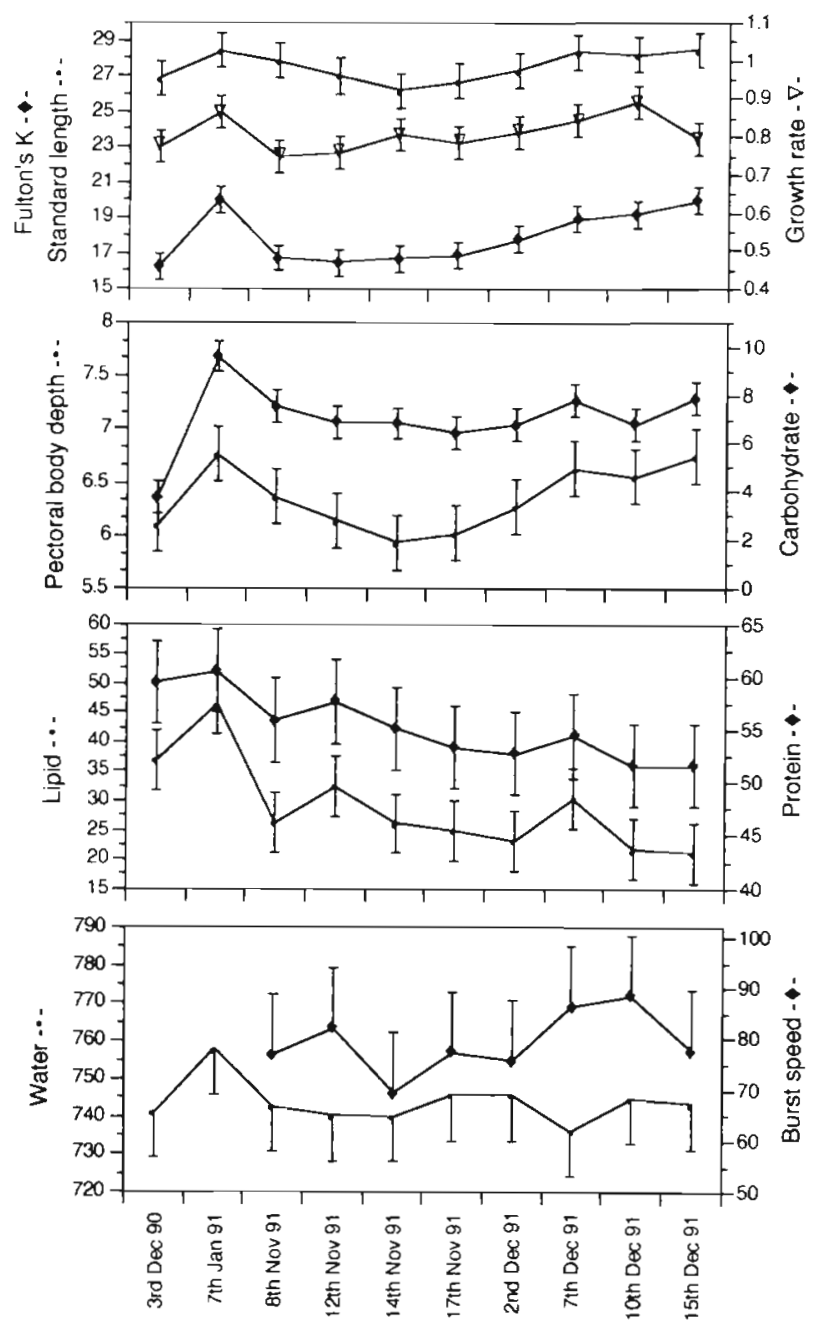

Fig. 6. Upeneus tragula. Comparison of 9 commonly used measures of fish condition in assessing the quality of 10 samples of newly settled fish. Error bars are $95 \%$ confidence limits $(n=10)$

The lack of relationship between fish length and burst speed conflicts with published accounts (e.g. Webb \& Corolla 1981, Fuiman 1986). For instance, Bailey (1984) found that escape speed of 5 larval fish species was strongly correlated with fish length, and

Table 3. Upeneus tragula. Nested ANOVA examining the effect of 5 different feeding levels during the late pelagic stage on burst speed at settlement. Percentage of variation explained by each factor is also given

\begin{tabular}{|lrccc|}
\hline $\begin{array}{l}\text { Source of } \\
\text { variation }\end{array}$ & df & Mean square & p & $\begin{array}{c}\text { Percent } \\
\text { variation }\end{array}$ \\
\hline Treatment & 4 & 630.87 & 0.2596 & 6.0 \\
Tank (treat.) & 5 & 348.52 & 0.0644 & 6.3 \\
Residual & 146 & 163.16 & & 87.7 \\
\hline
\end{tabular}

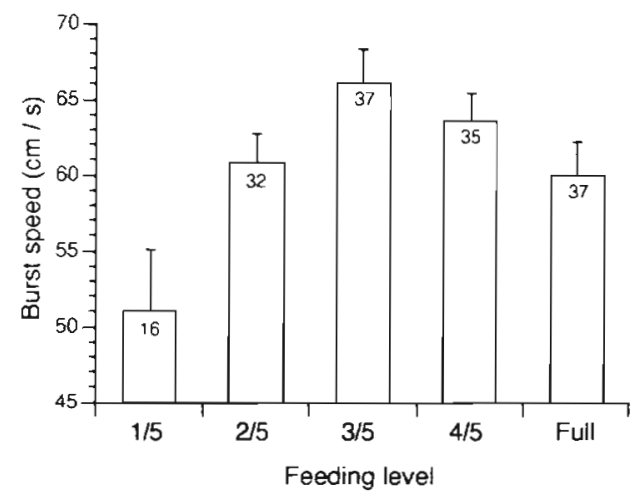

Fig. 7. Upeneus tragula. The effect of food quantity on the burst speed of fish at settlement. Error bars are standard errors ( $\mathrm{n}$ is variable and also given)

both length and escape speed closely predicted a fish's ability to avoid 3 invertebrate predators. There are a number of possible reasons for this discrepancy. All other examinations of burst swimming speed have encompassed a range of developmental stages rather than large numbers of fish from a single developmental stage as has been done in the present study. For example, Fuiman (1989) examined the vulnerability to predation of Clupea harengus larvae averaging 8.6 to $32.0 \mathrm{~mm}$ in length, representing 4 to $118 \mathrm{~d}$ posthatching. This alone may account for the difference between results. Further, the highest correlations have been attained for early larval stages, spanning hatching through to first feeding (e.g. Webb 1981, Webb \& Corolla 1981), when the behavioural response to the burst stimulus (probe, pipette or electric shock) is largely innate. In contrast, fish at settlement, with more fully developed sensory systems, are likely to exhibit a more individualistic response to the burst stimulus. Observations of newly settled Upeneus tragula, in both the field and tanks, suggest they are territorial and solitary for the first few days after settlement, in turn suggesting that they are well developed behaviourally. It is likely that the burst response is modified by the behavioural response of the individual fish to the simulated predator, thereby yielding a response not closely associated with fish length or biochemical composition.

Results from the feeding experiment further emphasized the individuality of the burst response. Differences in feeding history within the pelagic life stage accounted for only $6 \%$ of the tatal variation in burst speed of fish at settlement. This is of particular interest, since McCormick \& Molony (1992) experimentally examined the effect of feeding history on the growth attributes of Upeneus tragula at settlement and found that fish fed ad libitum during their late pelagic stages had better muscle development than 
less well fed fish. This lends support to the notion that individual behaviour influences the fish's burst speed. Furthermore it suggests that muscle development and burst speed represent differing aspects of overall body condition.

The burst speeds recorded in this study were considerably higher than those recorded for similarly sized fish of other species, reaching $42.5 \mathrm{BL} \mathrm{s}^{-1}$, with a mean of $29.5 \mathrm{BL} \mathrm{s}^{-1}$. By far the highest recorded burst speed is for larval stages (3.6 mm total length) of the Asian cyprinid Danio rerio at 50 to $66 \mathrm{BL} \mathrm{s}^{-1}$ (Fuiman 1986). However, burst speeds change ontogenetically (Wardle 1977). Evidence suggests that when burst speed is measured as $\mathrm{BL} \mathrm{s}^{-1}$, it is generally higher in early larval stages and decreases asymptotically with increasing length (e.g. Webb \& Corolla 1981, Wardle \& He 1988). Wardle \& He (1988) summarized the existing literature to date in a regression relationship predicting maximum speed for body lengths ranging from $13 \mathrm{~mm}$ to $2.4 \mathrm{~m}$. This calculation predicts that newly settled Upeneus tragula (mean length $27.8 \mathrm{~mm}$ ) should have a considerably lower maximum swimming speed of about $19 \mathrm{BL} \mathrm{s}^{-1}$ (i.e. $53 \mathrm{~cm} \mathrm{~s}^{-1}$ ). The relatively high burst speeds recorded in the present study may be due to the use of field-caught fish, rather than reared fish used in most other studies. A comparison of the speeds of fish put through trials the day after capture (Fig. 4) with those from the feeding experiment (Fig. 7) shows that rearing in tanks over the latter third of their pelagic existence caused a marked reduction in burst speed ( $81.8 \mathrm{cf}, 61.5 \mathrm{~cm} \mathrm{~s}^{-1}$ respectively). This suggests that published accounts of maximum speeds of reared fish may be substantial underestimates. It is not until other species of a similar developmental stage are caught from the field and submitted to tests that the importance of the speeds attained by $U$. tragula can be assessed.

In a similar way to burst speed, there was high variation in the energy storage components (lipids and carbohydrates) among newly settled fish. A large proportion of this variability was due to differences among samples (53 and $71 \%$ respectively), which stem from the pelagic ecology of the goatfish. McCormick \& Milicich (in press) found that the sampling strategy used in this study targets schools of larval goatfish. Once caught under rafts, fish were brought back to the laboratory where some metamorphosed and settled overnight. These newly settled fish are likely to have similar feeding histories, having experienced the same vagaries of food abundance and quality. If the schools are persistent this will result in the similarity of the biochemical composition found for Upeneus tragula within samples. For a reef fish at settlement the amount of energy stored as readily accessible carbohydrates and lipids may be important due to the changes in habitat, feeding mode and competitive regimes associated with the transition between pelagic and reef environments. The change to juvenile foraging patterns may take hours (in planktivores) to days (in demersal foragers; McCormick unpubl. data), and during this time of lower feeding efficiency stored energy may be used in competitive interactions or predator avoidance.

Low correlations among the 9 measures of condition (with the exception of SL and BDP) suggest that, within this developmental stage, there is no single measure of condition that will comprehensively describe a fish's ability to survive and compete in its environment. Each measure will address specific questions regarding the fish's condition. For instance, length, with its strong correlations with other morphological variables such as body depth and weight, may be useful in predicting the outcome of competitive interactions. On the other hand, lipid and carbohydrate content may be important in assessing which fish would best survive limited or unpredictable food resources. Theilacker (1978) noted that while morphological measures may reflect the nutritional condition of larval jack mackerel Trachurus symmetricus, no one criterion accurately identified larval condition on an individual basis. Neilson et al. (1986), in a laboratory study of larval Atlantic cod Gadus morhua, found that neither Fulton's $K$ nor relative body height was positively correlated with the performance of larvae in avoiding a simulated predator. We support the view of Theilacker (1978) and Neilson et al. (1986) that the rapid physiological and morphological changes that occur at developmental boundaries, such as metamorphosis or first exogenous feeding, may reduce the applicability of morphologically based descriptors of condition.

The lack of any strong relationships between specific aspects of the quality of newly settled Upeneus tragula and their length cautions against the direct transfer of size-based theories of the determinants of survival to the variability found within a particular developmental stage. Studies that have examined condition through ontogeny have found that body size is a useful predictor of quality since it is closely related to developmental status, especially in the larval stages when growth and differentiation are rapid (e.g. Miller et al. 1988). However, the present study has shown that at a particular developmental stage, size loses its predictive ability. The high variability present in all the measures of condition, and the documented link between many of these measures and survival (e.g. Rosenberg \& Haugen 1982, Bailey 1984, Folkvord \& Hunter 1986, Litvak \& Leggett 1992), suggests that this variability may be important in influencing which fish reach the reproductive population. 
Acknowledgements. For their enthusiastic assistance we thank Evi Seymour, Jenny Mcllwain, Vicki Hall and the staff of the Lizard Island Research Station. Many thanks to Maria Milicich, Dave Booth and Natalie Moltschaniwskyj for commenting on drafts of the manuscript. The project benefited from discussions with Howard Choat. Research was funded by the Australian Museum, through a Lizard Island Doctoral Research Fellowship (M.I.M.), and by an Australian Research Council minor research grant. Logistic support was provided by the Department of Marine Biology, JCU and the Leigh Marine Laboratory associated with the University of Auckland, NZ. This paper is a contribution from the Lizard Island Research Station, a facility of the Australian Museum.

\section{LITERATURE CITED}

Bailey, K. M. (1984). Comparison of laboratory rates of predation on five species of marine fish larvae by three planktonic invertebrates: effects of larval size on vulnerability. Mar. Biol. 79: 303-309

Bailey, K. M., Batty, R. S. (1984). Laboratory study of predation by Aurelia aurita on larvae of cod, flounder, plaice and herring: development and vulnerability to capture. Mar. Biol. 83: 287-291

Bailey, K. M., Houde, E. D. (1989). Predation on eggs and larvae of marine fishes and the recruitment problem Adv. mar. Biol. 26: 1-83

Beyer, J. E. (1989). Recruitment stability and survival - simple size-specific theory with examples from the early life dynamics of marine fish. Dana 7:45-147

Blaxter, J. H. S. (1988). Pattern and variety in development. In: Hoar, W. S., Randall, D. J. (eds.) Fish physiology 11(A). Academic Press, New York, p. 1-58

Bolger, T., Connolly, P. L. (1989). The selection of suitable indices for the measurement and analysis of fish condition J. Fish. Biol. 34: 171-182

Eaton, R. C., DiDomenico, R. (1986). Role of the teleost escape response during development. Trans. Am. Fish. Soc. 115 $128-142$

Folkvord, A., Hunter, J. R. (1986). Size-specific vulnerability of northern anchovy, Engraulis mordax, larvae to predation by fishes. Fish. Bull. U.S. 84: 859-869

Fuiman, L. A. (1986). Burst-swimming performance of larval zebra danios and the effects of diel temperature fluctuations. Trans. Am Soc. Fish. 115: 143-148

Fuiman, L. A. (1989). Vulnerability of Atlantic herring larvae to predation by yearling herring. Mar. Ecol. Prog. Ser. 51. 291-29

Gamperl, A. K., Bryant, J., Stevens, E. D. (1988). Effect of a sprint training protocol on growth rate, conversion efficiency, food consumption and body composition of rainbow trout, Salmo gairdneri Richardson. J. Fish. Biol. 33: $861-870$

Houde, E. D. (1989). Subtleties and episodes in the early life of fishes. J. Fish. Biol. 35 (Suppl.): 29-38

Laurence, G. C. (1972). Comparative swimming abilities of fed and starved larval largemouth bass (Micropterus salmoides). J. Fish. Biol. 4: 73-78

Litvak, M. K., Leggett, W. C. (1992). Age and size-selective predation on larval fishes - the bigger-is-better hypothesis revisited. Mar. Ecol. Prog. Ser. 81; 13-24

Love, R. M. (1980). The chemical biology of fishes, Vol. 2, Advances, 1968-1977. Academic Press, London

Margulies, D. (1989). Size-specific vulnerability to predation and sensory system development of white seabass, Atractoscion nobilis, larvae. Fish. Bull. U.S. 87: 537-552
Markle, D. F., Harris, P. M., Toole, C. L. (1992). Metamorphosis and an overview of early-life-history stages in Dover sole Microstomus pacificus. Fish. Bull. U.S. 90: 285-301

McCormick, M. I. (1992). The influence of pelagic life history on the quality of tropical goatfish (family Mullidae) at settlement. Ph.D. thesis, James Cook University, Townsville

McCormick, M. I., Milicich, M. J (in press). Late pelagicstage goatfishes: distribution patterns and inferences on schooling behaviour. J. exp. mar. Biol. Ecol.

McCormick, M. I., Molony, B. W. (1992). Effects of feeding history on the growth characteristics of a reef fish at settlement. Mar. Biol. 114: 165-173

McCormick, M. I., Shand, J. (in press). Metamorphosis of the visual and barbel sensory systems at settlement in the reef fish Upeneus tragula (family Mullidae). Proc. 7 th int. coral Reef Symp., Guam

Miller, T. J., Crowder, L. B., Rice, J. A., Binkowski, F. P. (1992). Body size and the ontogeny of the functional response in fishes. Can. J. Fish. Aquat. Sci. 49: 805-812

Miller, T. J., Crowder, L. B., Rice, J. A., Marschall, E. A (1988). Larval size and recruitment mechanisms in fishes: toward a conceptual framework. Can. J. Fish. Aquat. Sci. 45: $1657-1670$

Neilson, J. D., Perry, R. I., Valerio, P., Waiwood, K. G. (1986). Condition of Atlantic cod Gadus morhua larvae after the transition to exogenous feeding: morphometrics, buoyancy and predator avoidance. Mar. Ecol. Prog. Ser. 32: $229-235$

Pepin, P. (1989). Predation and starvation of larval fish: a numerical experiment of size- and growth-dependent survival. Biol. Oceanogr. 6: 23-44

Pepin, P. (1991). Effect of temperature and size on development, mortality, and survival rates of the pelagic early life history stages of marine fish. Can. J. Fish. Aquat. Sci. 48: $503-518$

Pfeiler, E. (1986). Towards an explanation of the developmental strategy in leptocephalous larvae of marine teleost fishes. Environ. Biol. Fish. 15: 3-13

Pfeiler, E., Luna, A. (1984). Changes in biochemical composition and energy utilization during metamorphosis of leptocephalous larvae of the bonefish (Albula). Environ. Biol. Fish 10: 243-251

Rosenberg, A. A., Haugen, A. S. (1982). Individual growth and size-selective mortality of larval turbot (Scophthalmus maximus) reared in enclosures. Mar. Biol. 72: $73-77$

Schwalme, K., Mackay, W. C. (1991). Mechanisms that elevate the glucose concentration of muscle and liver in yellow perch (Perca flavescens Mitchill) after exercisehandling stress. Can. J. Zool. 69: 456-461

Srivastava, R. K., Brown, J. A. (1991). The biochemical characteristics and hatching performance of cultured and wild Atlantic salmon (Salmo salar) eggs. Can. J. Zool. 69 $2436-2441$

Suthers, I. M., Fraser, A., Frank, K. T. (1992). Comparison of lipid, otolith and morphometric condition indices of pelagic juvenile cod (Gadus morhua) from the Canadian Atlantic. Mar. Ecol. Prog. Ser. 84: 31-40

Theilacker, G. H. (1978). Effects of starvation on the histological and morphological characteristics of jack mackerel Trachurus symmetricus, larvae. Fish. Bull. U.S. 76 403-414

Wardle, C. S. (1977). Effects of size on the swimming speeds of fish. In: Pedley, $T$ L. (ed.) Scale effects in animal locomotion. Academic Press, London, p. 299-313 
Wardle, C. S., He, P. (1988). Burst swimming speed of mackerel, Scomber scombrus L. J. Fish. Biol. 32: $471-478$

Weatherley, A. H., Gill, S. H. (1987). The biology of fish growth. Academic Press, New York

Webb, P. W. (1981). Response of northern anchovy Engraulis mordax larvae to predation by a biting planktivore Amphiprion percula. Fish. Bull. U.S. 79: 727-735

This article was presented by D. Kumpp, Townsville, Australia
Webb, P. W., Corolla, R. T. (1981). Burst swimming performance of northern anchovy Engraulis mordax larvae. Fish. Bull. U.S. 79: 143-150

Winer, B. J. (1971). Statistical principles in experimental design. McGraw-Hill, New York

Yin, M. C., Blaxter, J. H. S. (1987). Escape speeds of marine fish larvae during early development and starvation. Mar. Biol. 96: 459-468

Manuscript first received: November 26, 1992

Revised version accepted: March 30, 1993 